\title{
PREVENÇÃO CONTRA ZIKA POR MEIO DA PROPAGAÇÃO DE AÇÕES EDUCATIVAS NA ESCOLA CHUÍ EM MARACANAÚ (CE)
}

\author{
Janacinta Nogueira de Souza ${ }^{1}$ \\ Railane Sousa de Oliveira² \\ Aline Ribeiro Pinho ${ }^{3}$ \\ Youlia Milena Lopes Lima ${ }^{4}$ \\ Aline de Carvalho Oliveira ${ }^{5}$
}

Resumo: O mosquito Aedes aegypti é o vetor de diversas doenças tropicais, dentre elas a dengue, a Chikungunya e a Zika, além da Febre Amarela. A população brasileira, que já convive com surtos de dengue anualmente, tem agora a preocupação com estas outras doenças, em especial a Febre Zika ou simplesmente Zika, como ficou popularmente conhecida. Suspeita-se que sua entrada no Brasil ocorreu no período da Copa do Mundo de 2014, período em que houve intenso trânsito de turistas vindos de regiões endêmicas do vírus como Ásia, África e Ilhas do Pacífico e Chile. O referente artigo consistiu em realizar oficinas, palestras e apresentações lúdicas sobre formas de prevenção da Zika. O curso foi ministrado como uma iniciativa voluntária dos alunos, utilizando a infraestrutura da escola indígena Chuí e recursos financeiros extras para implementação das oficinas e atividades educacionais com os alunos, utilizando as salas de aula e espaços recreativos da própria escola, a qual dispõe de uma boa infraestrutura, quadro para escrita, retroprojetores, dentre outros. As ações deste artigo tiveram como objetivo repassar informações para evitar a proliferação do mosquito vetor da Zika e promover a prevenção contra a doença com ações educativas. O trabalho teve parceria do Instituto Federal de Educação, Ciência e Tecnologia do Ceará - Campus Maracanaú e Secretária de Saúde de Maracanaú.

Palavras-chave: Zika vírus; Aedes aegypti; Educação Ambiental.

\footnotetext{
${ }^{1}$ Instituto Federal do Ceará, Campus Maracanaú. E-mail: janacinta.nogueira@gmail.com

2 Instituto Federal do Ceará, Campus Maracanaú . E-mail: railaneso23@gmail.com

3 Instituto Federal do Ceará, Campus Maracanaú .E-mail: alinerp21@gmail.com

${ }^{4}$ Instituto Federal do Ceará, Campus Maracanaú . E-mail: youlia.Iopeslima@gmail.com

5 Instituto Federal do Ceará, Campus Maracanaú. E-mail: alinecaroli@gmail.com
} 


\section{Introdução}

A persistência da dengue e a recente introdução de outras arboviroses no Brasil, tais como a Chikungunya e a Zika, trazem ao país o desafio de combater, com eficiência, o mosquito vetor, o Aedes aegypti (CARDOSO et al, 2015). A população brasileira, que já convive com surtos de dengue anualmente, tem agora a preocupação com outras doenças, em especial a Zika, na qual os primeiros casos humanos autóctones registrados no país foram em 2015 (LIMA-CAMARA TN, 2016). Sendo, atualmente, transmitido em 21 unidades da federação brasileira, incluindo o Estado do Ceará (SUS, 2016).

A doença é causada pelo vírus da Zika, o ZIKV, e entrou para a realidade brasileira, com casos confirmados, em 2015. ZIKV é um arbovírus pertencente à família Flaviviridae, originalmente isolado em 1947 de uma fêmea de macaco Rhesus na Floresta Zika, na Uganda, de onde teve origem seu nome. Em humanos, o vírus foi isolado pela primeira vez em 1968 (MOORE et al, 1975).

É notório que a relação dos mosquitos vetores com o homem é um desafio, tendo em vista que o homem influencia o meio e este representa um obstáculo para o controle desses vetores. Meason e Paterso (2014) afirmam que o crescimento desordenado das cidades, acompanhado da poluição de rios e formação de valas, disponibiliza sítios de oviposição artificiais para a proliferação e disseminação dos mosquitos, principalmente o Aedes aegypti e o Culex. Quinquefasciatus. Os autores supracitados complementam que a maior frequência de chuvas em alguns locais acarreta no acúmulo de água, aumentando a oferta de criadouros naturais ou artificiais, em contrapartida, o período de seca em determinadas regiões obriga as pessoas a armazenaram água em tonéis ou em outros depósitos artificiais, que servem de criadouros para a proliferação e aumento da população dos vetores.

A história do Zika pode ser primariamente a de como certos tipos de ambientes urbanos e seus dejetos favorecem os mosquitos, mas o que é chocante é o quanto outros tipos de mudanças ambientais claramente pioram a disseminação de vetores de doenças (GAZETA DO POVO, 2016).

Suspeita-se que sua entrada no Brasil ocorreu no período da Copa do Mundo de 2014, período em que houve intenso trânsito de turistas vindos de regiões endêmicas do vírus como Ásia, África e llhas do Pacífico e Chile (SALVADOR; FUJITA, 2016).

Com sintomas similares aos da dengue, a Zika trouxe grande inquietação ao governo brasileiro, que tem realizado campanhas maciças de combate ao mosquito transmissor (BRASIL, 2016). A grande preocupação com o ZIKV está na sua relação com o aumento de casos de microcefalia em fetos (MLAKAR et al., 2016; VICTORIA et al, 2016) e outras neuropatias, como a síndrome de Guillain-Barré (FAUCl; MARENS, 2016).

Sabendo da sua importância para a saúde pública, são recomendáveis e imprescindíveis não só as pesquisas sobre sua disseminação, distribuição 
espacial, mas também a dispersão de políticas públicas ambientais pertinentes que visem sua erradicação.

Instrumento de política pública ambiental com atuação direta sobre o tema, a Educação Ambiental é dimensão educacional para a promoção da saúde, sendo necessárias ações educativas abrangentes, que possam alcançar efetivamente a população e assim reduzir os alarmantes números de Zika no Município.

O referente artigo teve o objetivo de promover a prevenção da Zika por meio de ações educativas enfatizando a relação do meio ambiente, do saneamento básico e da responsabilidade coletiva com as formas de prevenção da doença na Escola E.D.E.F.M de Chuí (escola Indígena) em parceria do Instituto Federal de Educação, Ciência e Tecnologia do Ceará Campus Maracanaú e da Secretária de Saúde de Maracanaú.

\section{Metodologia}

O projeto foi aplicado na escola indígena Chuí localizada no bairro Horto Florestal, Maracanaú-CE (Figura 1). A escola abrange Educação infantil, Educação de jovens e adultos - supletivo, ensino fundamental e ensino médio.

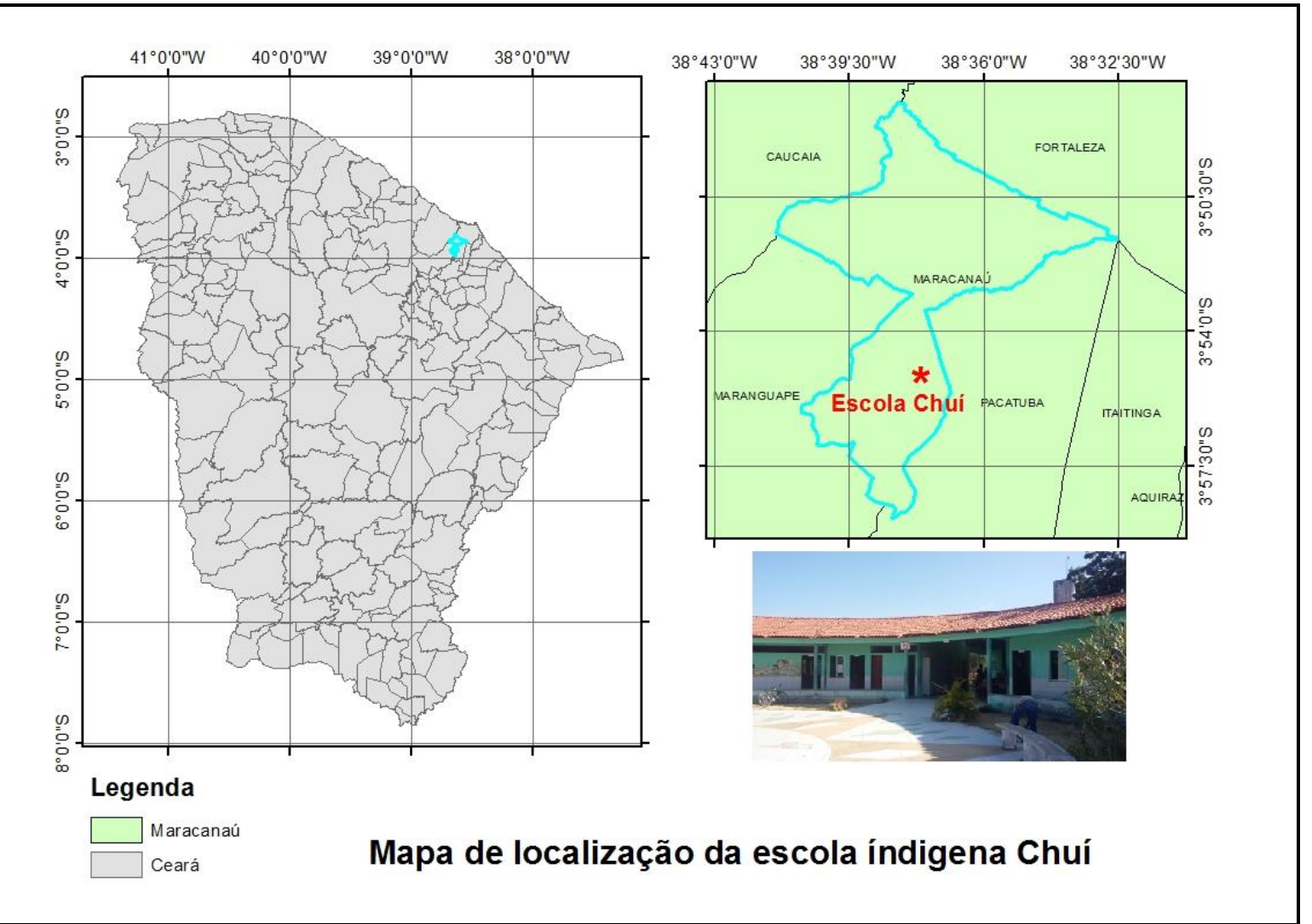

Figura 1: Localização da escola indígena Chuí.

Fonte: Souza (2017). 
Para levantamento bibliográfico acerca do tema proposto, foram realizadas visitas às Secretarias de Saúde do Município a fim de identificar a problemática da doença no município e identificar as políticas públicas aplicadas em prol da prevenção da doença.

O trabalho educativo e social ocorreu no período de junho de 2016 a novembro de 2016. O público alvo foram turmas do ensino fundamental II (6o ao $9^{\circ}$ ano). As atividades contemplaram aproximadamente 20 alunos/turma.

Para desenvolvimento de materiais didáticos e realização de palestras e/ou cursos foram utilizados materiais didáticos em forma de panfletos, dinâmicas, maquetes, apresentações didáticas em slides com vídeos e atividades lúdicas. O conteúdo dos materiais focou nas boas práticas para evitar a proliferação do mosquito Aedes aegypti e também os cuidados para evitar a picada do mosquito, tais como o uso de vestimentas fechadas e repelentes.

O curso foi ministrado como uma iniciativa voluntária dos alunos, utilizando a infraestrutura da escola indígena Chuí. Foram necessários recursos financeiros extras para implementação das oficinas e atividades educacionais com os alunos, utilizando as salas de aula e espaços recreativos da escola indígena Chuí, a qual dispõe de uma boa infraestrutura e equipamentos necessários para realização das atividades.

O projeto apresentou duas oficinas na escola Chuí visando aprofundar a abordagem da questão da Zika no contexto social da região. A primeira oficina foi realizada no dia 29 de agosto de 2016 com as turmas de $6^{\circ}$ e $7^{\circ}$ ano. A atividade foi feita com apresentações em dispositivos sobre histórico da doença, vetor, sintomas, transmissão, medidas profiláticas e tratamento (Figura 2). Ao término foi mostrado um vídeo didático sobre o Zika vírus a fim de despertar a atenção e o interesse dos alunos e melhorar a fixação do conhecimento dos mesmos sobre o tema. Após a aplicação da primeira oficina, foi realizada uma apresentação teatral em modelo de entrevista com um casal de mosquito Aedes aegypti, sobre questões relacionadas às informações apresentadas inicialmente (Figura 3 ). As vestimentas dos mosquitos foram adquiridas por intermédio de uma parceria do Instituto Federal do Ceará Campus Maracanaú com a prefeitura de Maracanaú por meio da Secretaria de Saúde e Mobilidade Social.

A segunda oficina foi realizada no dia 13 de outubro de $2016 \mathrm{com}$ as turmas de $6^{\circ}$, $7^{\circ}$ e $8^{\circ}$ ano (FIG. 4). A atividade contemplou a relação do saneamento básico para a prevenção do Zika vírus e apresentação de maquete. Dentro do conteúdo programático da segunda oficina foi abordada a importância da preservação e do bom gerenciamento do sistema de abastecimento de água, sistema de esgotamento sanitário, manejo dos resíduos sólidos e sistema de drenagem urbana para prevenção do mosquito Aedes aegypti. 


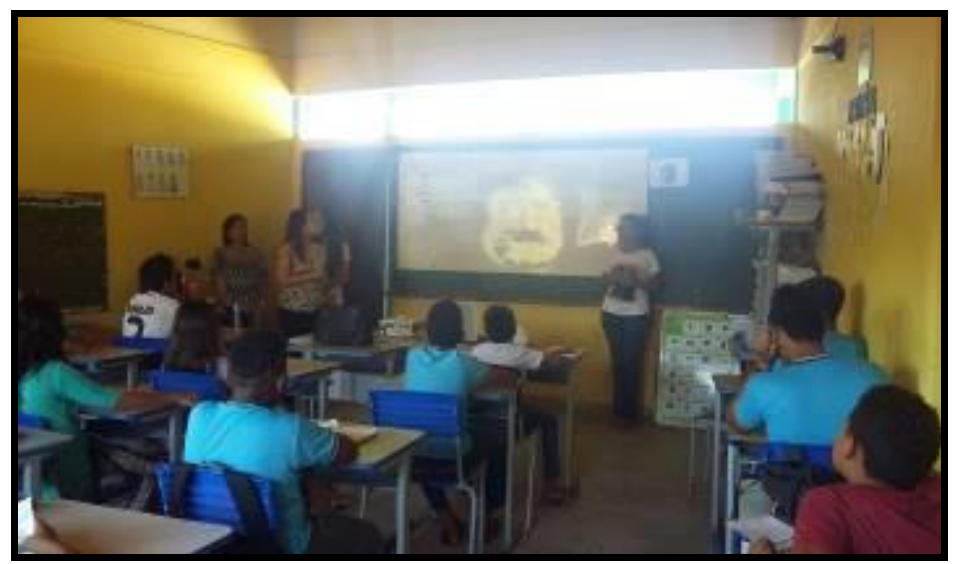

Figura 2: Realização da primeira oficina.

Fonte: Souza (2016).

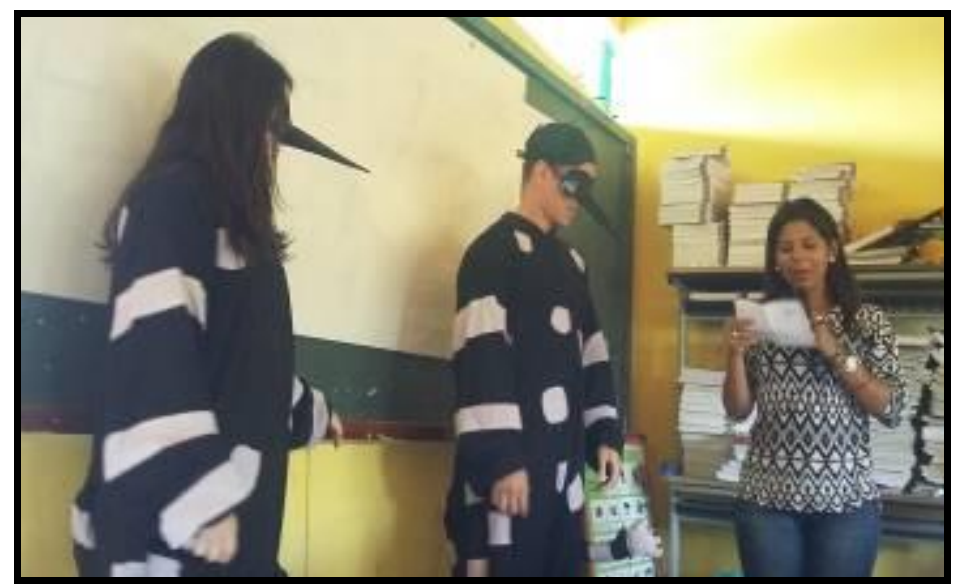

Figura 3: Entrevista com um casal de mosquito Aedes aegypti. Fonte: Souza (2016).

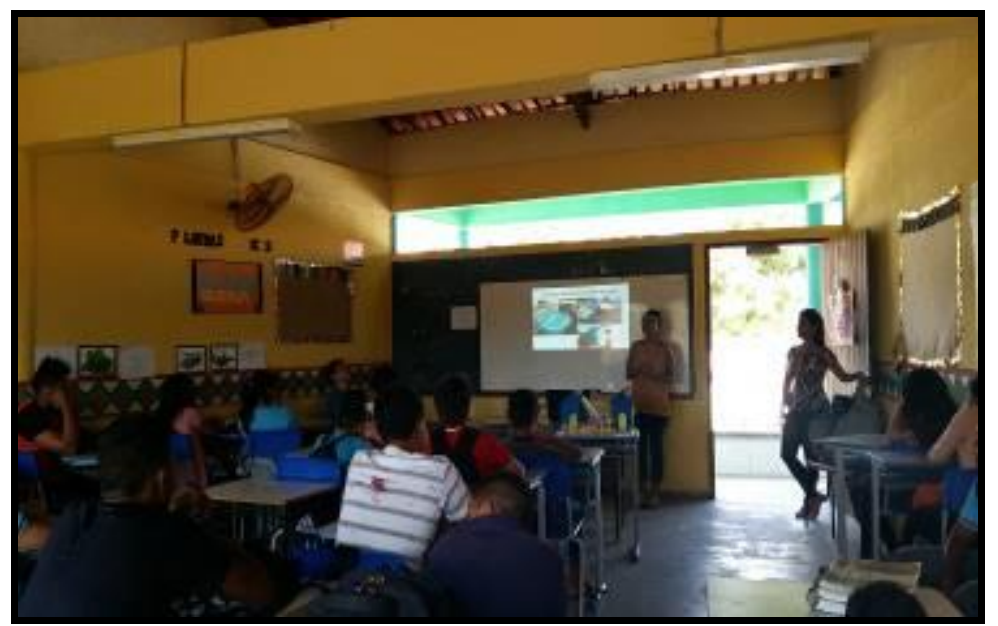

Figura 4: Realização da segunda oficina com as turmas de $6^{\circ}$ e $7^{\circ}$ ano.

Fonte: Souza (2016). 
Como uma forma criativa e lúdica de rever e reforçar os conhecimentos da primeira oficina foi apresentado uma maquete representada por uma casa certa e uma casa incorreta com relação às formas de proliferação do mosquito Aedes aegypti (Figura 5). A atividade foi aplicada por ação voluntária dos alunos que inicialmente identificaram a casa certa e a casa errada e em seguida explicaram aos colegas de classe o que estava certo e errado nas casas que facilitam a proliferação do mosquito Aedes aegypti.

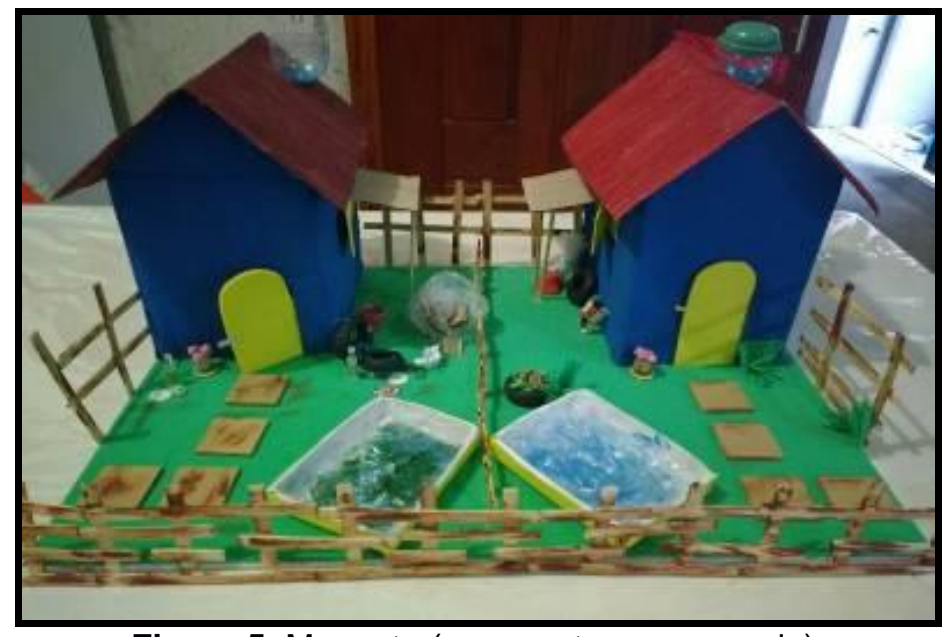

Figura 5: Maquete (casa certa, casa errada).

Fonte: Souza (2016).

Por fim, foram aplicados questionários impressos para avaliar o desempenho do projeto e a capacidade de assimilação do conteúdo por parte dos alunos. O questionário aplicado foi composto por campos de identificação e caracterização (nome, bairro, idade, sexo, série e turno) e campos sobre a transmissão, o vetor e seu ciclo de vida, proliferação do mosquito transmissor, medidas de prevenção, dentre outras.

As informações registradas foram tabuladas em formulários on-line do google, possibilitando a análise estatística. Os formulários foram aplicados em todas as turmas do ensino fundamental II do turno da tarde. A turma de $9^{\circ}$ ano e os não participantes atuaram como o grupo de controle da pesquisa.

\section{Resultados e discussões}

A direção da escola demonstrou total apoio e interesse na realização do projeto. Reconheceu a importância social e ambiental deste como ferramenta importante e eficaz na conscientização dos alunos quanto ao tema.

As atividades foram ministradas com as turmas de $6^{\circ}$ e $7^{\circ}$ ano separadas das turmas de $8^{\circ}$ e $9^{\circ}$ ano, buscando uma ação única que fosse condizente com cada faixa etária.

Participaram do formulário avaliativo de desempenho do projeto 39 pessoas, o que correspondeu a aproximadamente $9,47 \%$ do quantitativo total Revbea, São Paulo, V. 13, № 4: 379-389, 2018. 
da escola, prevalecendo participantes com faixa etária entre 12 a 15 anos. $52,8 \%$ dos alunos (participantes) eram do sexo masculino e $47,2 \%$ do sexo feminino. Das 36 respostas obtidas $85,8 \%$ dos participantes moravam nos bairros Olho d'água e Horto. A turma do $7^{\circ}$ ano teve a maior parcela de respostas nos formulários com $31,6 \%$ dos participantes (Figura 6). Observouse maior ação participativa dos alunos de $6^{\circ}$ e $7^{\circ}$ ano, que sempre perguntavam e comentavam a respeito do tema durante a aplicação das atividades, além disso eram alunos mais agitados e hiperativos quando comparados aos alunos de séries superiores. Essa maior participação pode ser explicada partindo da premissa que esses alunos ainda estão em transição para a fase "puberal", marcada pelo aparecimento das modificações fisiológicas e mudanças psíquicas, ou seja, adolescentes que irritam-se facilmente, tornamse arredios, explosivos e preferem manter-se isolados (CARVAJAL, 1998).

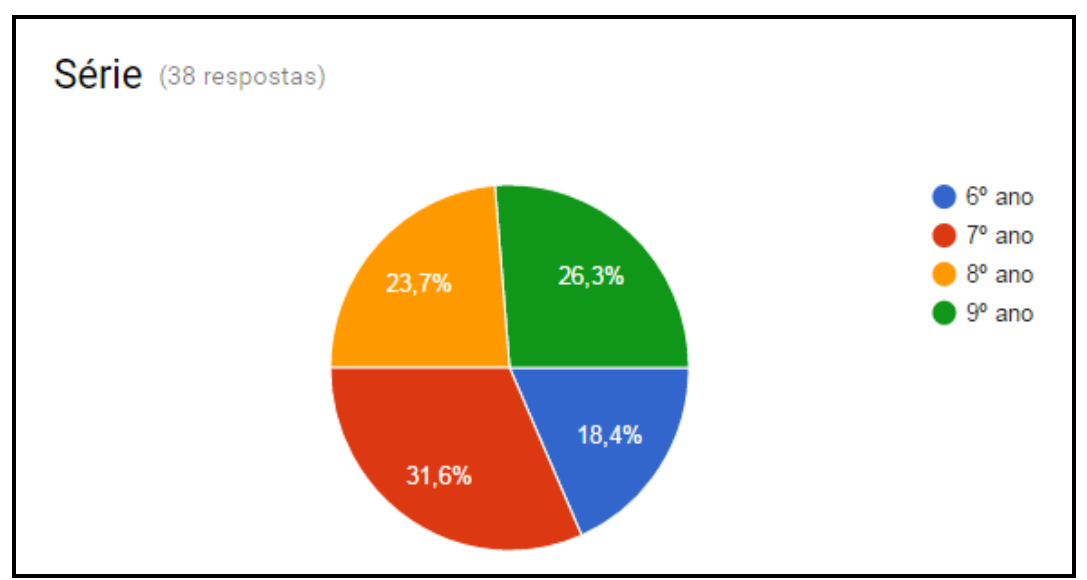

Figura 6: Série dos participantes. Fonte: Souza (2016).

Somente $25,6 \%$ dos alunos que preencheram o formulário não participaram de nenhuma atividade do projeto. A maioria dos alunos, representados por $58,6 \%$, participaram somente da $2^{\circ}$ oficina, na qual foi abordada a relação do saneamento básico com a prevenção do Zika vírus, $27,6 \%$ participaram somente da $1^{\circ}$ oficina, que abordou os conceitos básicos sobre a doença e 13,8\% participaram de ambas as oficinas.

$\mathrm{O}$ desempenho dos palestrantes foi muito bem avaliado pelos alunos, onde $79,3 \%$ deles avaliaram como 'ótimo' e 17,2\% como 'bom'.

A maioria dos alunos não tiveram dificuldades em identificar o principal mosquito transmissor do Zika vírus, pois $87,2 \%$ responderam que era o Aedes aegypti. Durante a aplicação da primeira oficina os alunos demonstraram conhecimento a respeito da Zika e relataram alguns casos particulares de contágio da doença. Alguns comentaram já terem visto o mosquito Aedes aegypti de perto e outros comentaram terem visto somente por imagens.

Embora a maioria dos alunos tivesse ciência sobre o mosquito transmissor da Zika, foi constatada a falta de conhecimento sobre a morfologia 
e o ciclo de vida do vetor, pois os alunos tiveram dificuldades em identificar e diferenciar a larva e a pupa. Somente $40,5 \%$ conseguiram identificar as 4 fases do ciclo de vida do mosquito transmissor (Figura 7). Durante aplicação das atividades os alunos também se demonstraram surpresos quanto ao rápido ciclo reprodutivo do vetor e a quantidade de ovos gerados pelo mosquito fêmea.

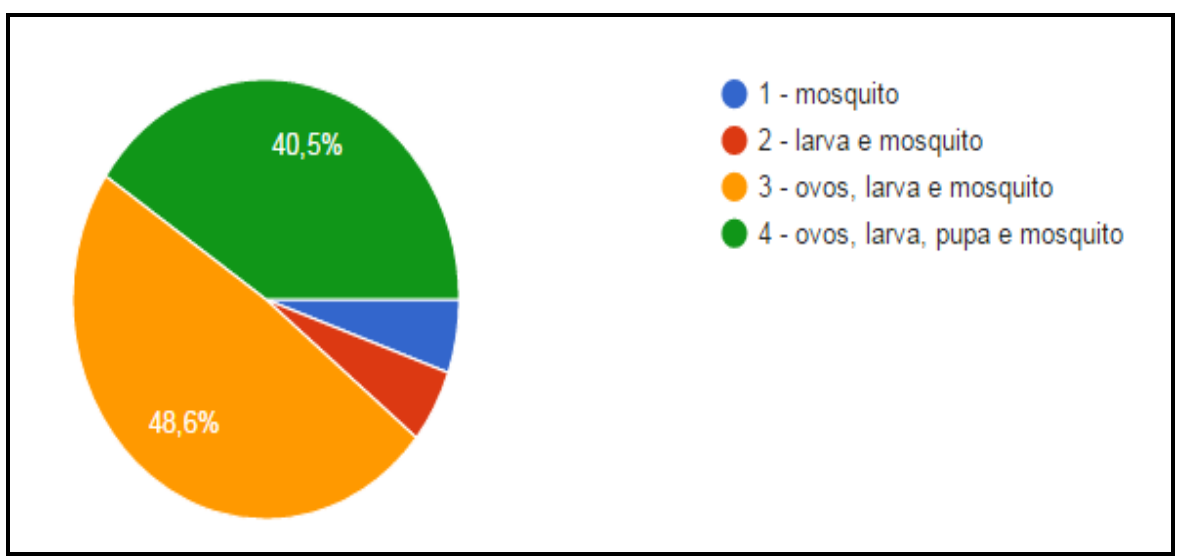

Figura 7: Fases do ciclo de vida do mosquito transmissor da Zika.

Fonte: Souza (2016).

Ainda de acordo com o formulário, $100 \%$ dos participantes afirmaram terem encontrado foco do mosquito transmissor, sendo a maioria dos focos encontrados em casa e nas ruas (Figura 8).

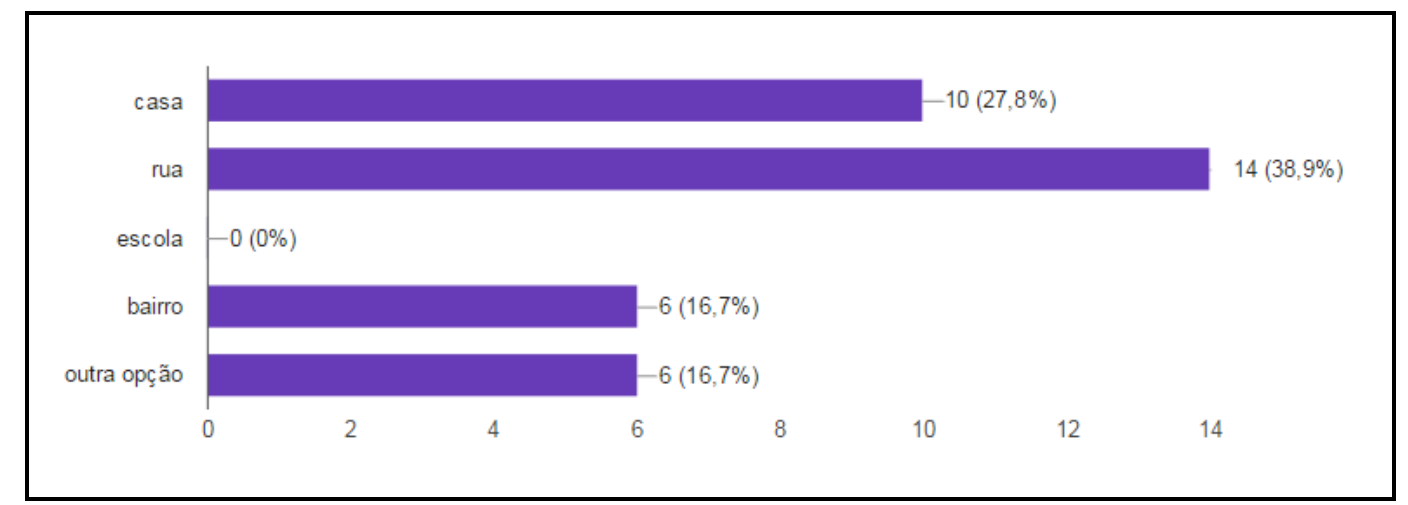

Figura 8: Local onde foi encontrado foco de mosquito transmissor do zika vírus. Fonte: Souza (2016). 


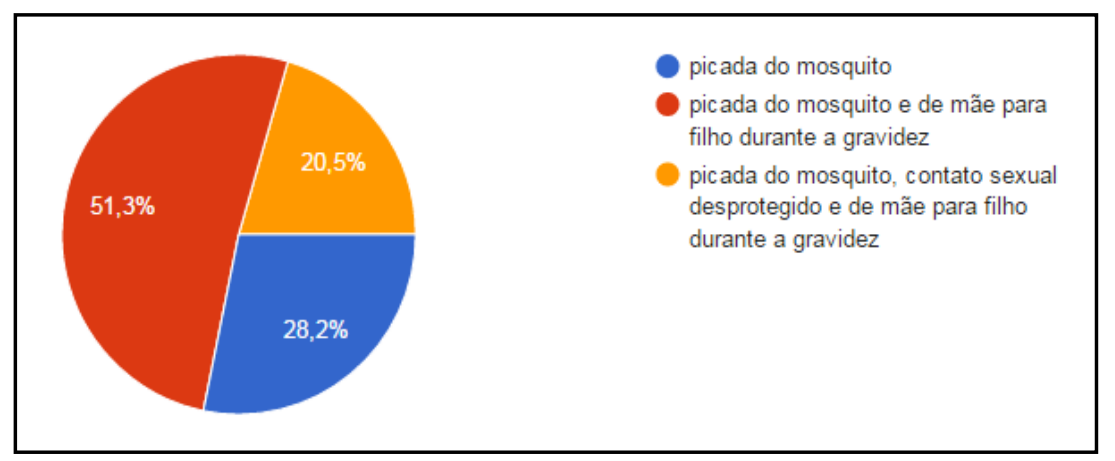

Figura 9: Nível de conhecimento sobre as formas comprovadas cientificamente de transmissão do Zika vírus. Fonte: Souza (2016).

Quando perguntados sobre os riscos para as mulheres grávidas que contraem o Zika vírus, 92,1\% dos alunos reconheceram a possibilidade de haver riscos, porém um dado preocupante é que $60 \%$ dos participantes desconheciam o risco e somente $34,3 \%$ dos participantes afirmaram ter conhecimento de que o risco era a microcefalia. Com esse resultado, fica notória a importância e a necessidade da transmissão de informação no âmbito educacional. Os alunos demonstraram bastante curiosidade e avidez pelas informações prestadas sobre 0 assunto.

Outro ponto interessante analisado durante a aplicação das atividades foi o conhecimento dos participantes a respeito do tratamento e prevenção da doença. Quando questionados sobre o tratamento, a maioria comentou somente a consulta imediata ao médico, o repouso e a ingestão de líquidos, porém muitos se demonstraram surpresos quanto ao uso de roupas longas e ao uso de mosquiteiros. Quando indagados sobre as dicas de prevenção, a maioria demonstrou conhecimento prévio e foram bastante participativos.

Durante a aplicação da segunda oficina, os alunos demonstraram inicialmente desconhecimento sobre saneamento básico e suas vertentes. Porém, um percentual expressivo de participantes conseguiu identificar após a aplicação do projeto alguns dos principais problemas de saneamento ambiental relacionados à proliferação do mosquito Aedes aegypti. No entanto, somente $34,2 \%$ dos participantes conseguiram identificar todas as opções corretas.

Com relação ao grau de incidência da doença nas localidades próxima à escola, $57,9 \%$ dos participantes afirmaram conhecer alguém que já teve o Zika vírus. Assim, ressalta-se a importância de ações educativas de caráter informativo e preventivo nas escolas.

Os alunos demonstraram interesse em participar da atividade com a maquete (Figura 5) e não apresentaram dificuldades na identificação dos erros e acertos com relação à proliferação dos focos do mosquito. Perceberam que na "casa incorreta" os pneus eram dispostos ao ar livre, os recipientes que acumulavam água estavam abertos, as garrafas estavam jogadas no quintal, a caixa d'água estava aberta e o lixo espalhado pelo quintal, já na "casa correta" os alunos identificaram que os pneus foram reaproveitados para jardinagem e 
armazenados em locais cobertos, a caixa d'água estava tampada e vedada, as garrafas estavam viradas de cabeça para baixo, dentre outros detalhes.

\section{Conclusão}

O projeto, com foco na educação ambiental, obteve uma excelente aceitação da escola indígena Chuí, que contribuiu com as práticas de sensibilização e motivação dos jovens na construção de conhecimentos preventivos da Zika e dos impactos sócios ambientais relacionados.

É de notória importância a realização dessas atividades educativas, a fim de conscientizar o corpo docente, servidores administrativos, discentes e à comunidade relacionada, tendo em vista que nós, como cidadãos, temos a maior parcela de responsabilidade e fiscalização das ações de prevenção e diminuição da incidência da doença.

A criação de algumas possibilidades e condições favoráveis, enobrecida pela instrumentalização das informações, fizeram com que alunos e professores pudessem refletir sobre suas práticas e passassem a atuar num clima mais condizente com a realidade da escola, facilitando o reconhecimento e a valorização de suas ações.

Uma grande contribuição do projeto foi a formação de multiplicadores ambientais, que podem atuar na disseminação dos conhecimentos e das habilidades adquiridos ao longo do tempo, estimulando o desenvolvimento permanente das boas práticas ao combate da Zika e outras doenças.

No entanto, sugere-se que atividades paralelas sejam implementadas de forma contínua para garantir a eficácia na prevenção da Zika e outras doenças, pois apesar de ser um tema bastante debatido na mídia e por outros meios de comunicação, as informações, muitas vezes, não são recebidas com a devida importância pela comunidade.

\section{Referências}

BRASIL, Voz do Brasil. Combate a Zika. Brasília: Rádios Abertas, 17 de fevereiro de 2016. 19h. Programa de rádio.

BRASIL, Ministério da Saúde. Boletim Epidemiológico Secretaria de Vigilância em Saúde. n. 6, v. 47, 2016.

BRASIL, Portal da Saúde. Disponível em: <http://portalsaude.saude.gov.br /index.php/o-ministerio/principal/secretarias/svs/zika> Acesso em 18 fev. 2016.

CAMPOS, G.S., BANDEIRA, A.C., SARDI, S.I. Zika virus outbreak, Bahia, Brazil. Emerg. Infect. Dis. n. 21, v.10, 2015. 
CARDOSO, C.W.; PAPLOSKI, I.A.; KIKUTI, M.; RODRIGUES, M.S.; SILVA, M.M.; CAMPOS, G.S.; et al. Outbreak of exanthematous illness associated with Zika, Chikungunya, and Dengue viruses, Salvador, Brazil. Emerg Infect Dis, 2015.

CARVAJAL, G. Tornar-se adolescente: a aventura de uma metamorfose. São Paulo: Cortez, 1998.

FAUCI, A.S.; MORENS, D. M. Zika Virus in the Americas - Yet Another Arbovirus Threat. N. Engl. J. Med., 2016.

GAZETA DO POVO. Saúde. Brasil, 05 fev. 2016. Disponível em: $<$ http://www.gazetadopovo.com.br/saude/lixo-e-desmatamento-estao-entre-ascausas-ambientais-da-proliferacao-do-zika-732iu6h9rvpqljud3rc50z4ds >. Acesso em: 10 out. 2016.

LIMA-CAMARA TN. Arboviroses emergentes e novos desafios para a saúde pública no Brasil. Rev Saúde Pública. 2016.

MEASON, B.; PATERSON R. Chikungunya, climate change, and human rights. Health Hum Rights. 2014; v.16, n.1, pp.105-112.

MLAKAR, J. et al. Zika Virus Associated with Microcephaly. N. Engl. J. Med., 2016.

MOORE, DL et al. Arthropod-borne viral infections of man in Nigeria, 19641970. Ann Trop Med Parasitol. n. 69, v.1, p. 49-64, 1975.

OEHLER, E. et al. Zika virus infection complicated by Guillain-Barré syndrome: case report, French Polynesia, December 2013. Euro Surveill. n. 19, v.9, 2014.

PORTAL DA SAÚDE - SUS. Novos casos suspeitos de microcefalia são divulgados pelo Ministério da Saúde. Boletim. Disponível em: $<$ http://portalsaude.saude.gov.br/index.php/cidadao/principal/agencia-saude/ 21677-novos-casos-suspeitos-demicrocefalia-sao-divulgados-peloministerio-da-

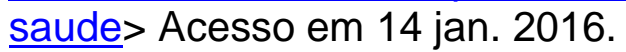

SALVADOR, F.S.; FUJITA, D.M. Entry routes for Zika virus in Brazil after 2014 world cup: New possibilities. Travel Medicine and Infectious Disease. 2015.

VICTORIA, C.G. et al. Microcephaly in Brazil: how to interpret reported numbers? Lancet, 2016.

YANG, H.M. et al. Dinâmica da transmissão da dengue com dados entomológicos Temperatura-dependentes. Tend. Mat. Apl. Comput., v.8, n. 1, p. 159-168, 2007. 